\title{
The Implementation of Business Strategy and Management
} \section{Accounting Practice to Increase Competitive Advantage in Fashion-Based Creative Industry}

\author{
Diana Zuhroh, Sunardi \\ University of Merdeka Malang, Kota Malang, Indonesia
}

\begin{abstract}
This study aimed to obtain empirical evidence related to: (1) competitive strategy implemented by small and medium-size enterprises (SMEs) fashion sector; (2) management accounting system practiced by SMEs fashion sector; and (3) analyze whether the existing accounting system, in accordance with contingency theory is adequate to support strategy implementation. The object of this study is SMEs engaged in the fashion sector with research variables are: competitive strategy and management accounting practices. Methods of data collection using questionnaires with respondents are owners of SMEs fashion sector. Data analysis used quantitative descriptive analysis. The result of data analysis shows that most of SMEs which become sample of this research have been exporting or planned to export its product. Based on further analysis, most of SMEs engaged in the sector have not yet prepared financial statements. The most important accounting records are records of receivables, cash inflows, and cash outflow. With these results, it can be concluded that the fashion-based SMEs sector has not been supported by adequate management accounting system to support the implementation of competitive strategy. In order to improve the competitive advantage of fashion-based SMEs, it is necessary to assist management accounting system as a provider of information that can be used as a basis for decision-making in accordance with the strategy implemented.
\end{abstract}

Keywords: competitive strategy, practice of management accounting system, competitive advantage

\section{Introduction}

According to the Ministry of Tourism and Creative Economy of the Republic of Indonesia (2014), the growth of creative use increased by an average of $10.5 \%$ per year during $2010-2013$, absorbed about $10.6 \%$ of the total national workforce. Furthermore, in the development of creative economy, the government has set 15 priority sectors namely: (1) architecture; (2) design; (3) film, video, and photography; (4) culinary; (5) crafts; (6) fashion; (7) music; (8) issuance; (9) interactive games; (10) advertising; (11) research and development; (12) fine art; (13) performing arts; (14) information technology; and (15) television and radio.

Of the 15 creative sub-sectors developed, three of them recorded the largest contribution to gross domestic product (GDP): culinary of $32.5 \%$, fashion by $28.3 \%$, and craft $14.4 \%$. The government is targeting the GDP

Diana Zuhroh, Dr., CA, Head of Magister in Accounting, University of Merdeka Malang, Kota Malang, Indonesia.

Sunardi, Dr., Head of Tourism Diploma, University of Merdeka Malang, Kota Malang, Indonesia.

Correspondence concerning this article should be addressed to Diana Zuhroh, Graduate School Building, Jl. Terusan Raya Dieng 59, Malang, East Java, ZIP 65146, Indonesia. 
contribution from the creative economy to reach 7-7.5\% in next 2019 (Mutmainah, 2016). As expressed by Muslikah (2014), fashion industry becomes a potential industry for Indonesian GDP contributors and can be relied upon as a potential employer as a solution to overcome the number of unemployed in Indonesia.

The Government of Indonesia through the Ministry of Tourism and Creative Economy defines fashion in the creative economy as "a lifestyle in appearance that reflects self or group identity". The scope of industry in this field includes: clothing design, footwear, fashion accessories, clothing production and accessories, fashion product line consultation, and fashion product distribution (Ministry of Trade of the Republic of Indonesia, 2015). However, in reality, this sector is still facing a major problem.

The various studies concluded that the problems faced by this sector are: inadequate formal and non-formal education (see http://ranahberita.com), intense competition with imported products (Kontan, July 19, 2017), the inefficiency that causes low competitiveness of Indonesian products in global markets (Gunadi, 2017), and lack of access to funds from banks (Indonesian Central Bank, 2015). Generally, in Indonesia, micro and SME businesses (including creative industry sector) are not covered by banking services and lending from formal finance institutions, so they use shadow banks that charge much higher interest rates (Organisation for Economic Co-operation and Development [OECD], 2015, p. 13).

Referring to contingency theory, in order to survive as a general company, the fashion-based SME sector also requires competitive strategies and adequate management accounting systems. Management accounting systems play an important role in providing both financial and non-financial information required by management for both operational and strategic decision-making. In other words, the management accounting system should be able to play as supporting role in implementing strategy that chosen by the organization through the provision of useful information for planning, directing, and encouraging efforts to achieve organizational goals (Langfield-Smith, 2007, p. 243). This condition should be achieved by small and medium enterprises because this sector also faces very tight competition as experienced by large-scale companies.

As explained earlier, the serious internal problem faced by the SMEs fashion sector is not yet having a good financial and management administration system (Indonesian Central Bank, 2015, p. 20). As a result, an estimated 60-70\% of SMEs have not accessed bank financing (Indonesian Central Bank, 2015, p. 18). This research is conducted to obtain empirical evidence related to: (1) competitive strategy implemented by SMEs fashion sector; (2) management accounting system practiced by SMEs fashion sector; and (3) analyze whether the existing system is adequate to support the implementation of strategy. Theoretically, the results of this research will be useful in the development of contingency theory, especially the fit or alignment between the implementation of competing strategies with management accounting practices. In practical level, the results of this research is useful as a basis in conducting the guidance to the creative industries development, especially SMEs fashion sector, whether that will be done by the government, academics and other parties who are related to this sector.

\section{Fashion-Based Creative Industry}

According to Subagja (2017), the creative industry needs to be developed because: (1) contribute to economic improvement; (2) creating a positive business climate; (3) building the image and identity of the nation; (4) based on renewable resources; (5) creating innovation and creativity is a competitive advantage of a nation; and (6) provide a positive social impact. 
According to Ministry of Tourism and Creative Economy (2014, p. 222), the definition of the fashion is: (1) a combination of styles that have a tendency to change and up to dates; (2) an acceptable, popular choice, and is used by the majority of the public; (3) a means to be accepted by the general public as a symbol of expression of a particular identity to provide confidence in the appearance of the wearer; and (4) not only always about dressing, imaging, or designing clothing, but also the role and meaning of clothing in social action. Based on that definition, especially the first definition, it can be concluded that fashion is not something static or fixed, but rather changes over time because the fashion always displays an update. This means, in fashion, there is also a cycle: appear, favored, and then, abandoned by the wearer.

Along with the development of society, the fashion industry also experienced the development, from just a home-based activity to a large-scale industry. Business fields created from the fashion industry include: business in textiles, leather, knitting and garments, trading (distributor) of local and international fashion products (export and import), as well as services especially designer services (Muslikhah, 2014). The chain of fashion industry also has a very wide coverage, especially textile-based fashion products that are supported by raw material suppliers as well as other materials that are widely available in Indonesia (Indonesian Ministry of Industry, 2009).

\section{Management Accounting System to Support Implementation of Competitive Strategies}

Competitive strategy is offensive or defensive action to create a safe position (defendable) in the industry to win the competition and gain high profits. Organizations are considered to require competitive strategies as a means that organizations must create to cope with environmental change. According to Porter (1980, p. 39), there are three generic strategies that usually used by the company are: differentiation, low cost, and focus. Differentiation strategy is an effort to differentiate the products or services the company offers by creating something new and perceived as unique by the whole industry (Porter, 1980, p. 37). The uniqueness is expected to increase consumer loyalty which further leads the company to higher profit margin than its competitors. Meanwhile, low cost strategy is a strategy used to win the competition by relying on low overall cost so as to achieve efficiency compared to competitors. Efficiency is achieved through strict control over overhead costs including research and development costs, service, sales, advertising, and other costs (Blocher, Stout, \& Cokins, 2010, p. 16).

To support the implementation of management strategies, a management accounting system is required that provides various information, both financial and non-financial. Accounting researchers argue about the importance of enhancing the role of management accounting in helping companies to achieve competitive advantage. Management accounting is an information provider for ongoing management processes including for the implementation of strategies with the help of information technology (Phadoongsitthi, 2003). The management accounting system should also be able to play a supporting role in realizing the strategy chosen by the organization through the provision of useful information for planning, directing, and encouraging efforts to achieve organizational goals (Langfield-Smith, 2007, p. 243).

From various studies, currently information is a key resource to achieve success. The accounting system plays an important role as the producer of most of the information required by managers for decision-making (Hansen, \& Maryanne, 2007). Companies operating in an environment with high uncertainty and intense competition require useful information in formulating and implementing strategies. Therefore, companies need a management accounting system that is able to reflect long-term relationship with the environment including employees, consumers, suppliers, and other stakeholders (Nishimura, 2005, p. 230). 
Contingency theory is a theory that is widely used in research especially that aims to examine the influence of factors both internal and external to the organizational structure, which ultimately affects the performance of the organization. The linkage between competing strategies and management accounting within the framework of contingency theory is described in Figure 1.

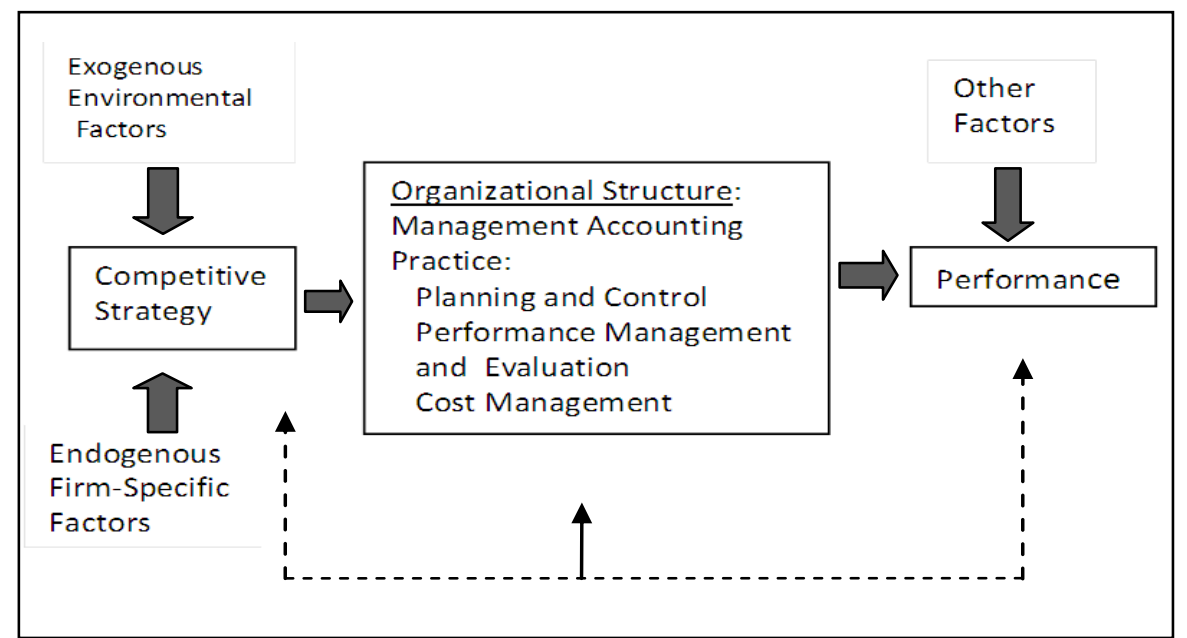

Figure 1. The linkage between competing strategies with management accounting practicesin the contingency theory framework (Source: Anderson \& Lanen, 1999).

Based on Figure 1, contingency theory is related to strategy-structure-performance paradigm, that is, the synergy between strategy and organizational structure to maximize performance in response to exogenous factors. Furthermore, contingency theory also assumes that organization is a function of several factors simultaneously influenced by external environmental factors and other factors. The organizational structure in the model includes management accounting practices, formal and informal information, and decision-making.

Studies emphasizing the importance of strategic roles associated with other contingency variables, especially environment, technology, organizational structure, and management control systems are considered to be increasingly important (Chenhall, 2007, p. 164). Furthermore, the role of the management accounting system in support of formulation, implementation, and strategy changes becomes the next emphasis (Langfield-Smith, 2007, p. 755).

Companies that implement differentiation strategies require a rapid response to changing consumer tastes and are constantly actively monitoring market changes. In addition, the company also needs useful information to perform customer satisfaction analysis, and delivery accuracy analysis and other analysis. These conditions cause companies to require both financial and non-financial information and strategic management accounting system is a system that is considered capable of providing information required by companies that implement differentiation strategies.

Conversely, firms that implement low cost efficiency strategies generally emphasize on the processes that take place in the company running on time and efficiently (Baines \& Langfield-Smith, 2003; Jermias \& Gani, 2004). Therefore, a low cost strategy requires useful financial information to monitor efficiency achievement across all value chains in order to establish a lower selling price than competitors. A management accounting system that provides information with greater emphasis on financial aspects is a traditional management accounting system. 


\section{Research Methods}

\section{Unit of Analysis}

The object of this study is SMEs engaged in the fashion sector which includes companies that make products made from batik (textile motif typical Indonesia), and embroidered products, garments, also other creative industries related to fashion. Batik products and apparel made from batik are superior product in East Java Province. The unit of analysis of this research is an export-oriented, micro and small (SME) fashion business.

\section{Research Variables}

The variables of this research are: competitive strategy and management accounting practice. In this research, the implementation of competitive strategy by company is divided into: low cost and differentiation. Meanwhile, the practice of management accounting is a management accounting technique used to record transactions and economic events that occur in SMEs fashion sector.

\section{Respondents, Data Collection Methods, and Data Analysis Techniques}

Research respondents, research data collection, and data analysis techniques are presented in Table 1.

\section{Analysis of the Data}

Analysis of the data is done with the following stages:

1. Identify costs incurred by respondents, which include: research and design costs, production costs, and marketing/distribution costs, as well as after-sales service costs.

Table 1

Method of Collecting Data, Respondents, Questions in the Questionnaire, and Analysis of the Data

\begin{tabular}{|c|c|c|}
\hline 1 & Method of collecting data & Questionnaire. \\
\hline 2 & Respondents & Small business owner or entrepreneur from the fashion sector in East Java Province. \\
\hline 3 & $\begin{array}{l}\text { Questions in the } \\
\text { questionnaire }\end{array}$ & $\begin{array}{l}\text { 1. Profiles of respondents include: product type, domestic marketing, export destination } \\
\text { country, and main competitor countries. } \\
\text { 2. The general profile of the respondents. } \\
\text { 3. Cost structure that includes: } \\
\text { a. Research and design costs } \\
\text { b. Production Costs } \\
\text { c. Marketing and Distribution Costs } \\
\text { d. Service After Sales Costs } \\
\text { Questions relating to the level of application of competitive strategies consist of } 8 \\
\text { questions, with details: questions } 1-4 \text { for implementation of differentiation strategies, } \\
\text { while question 5-8 for low cost strategy implementation. For differentiation strategy, } \\
\text { questions were about policies directed to create unique products and services for } \\
\text { consumers. As for the low cost strategy, questions were about the policy directed in } \\
\text { achieving efficiency and low pricing. Respondents were asked to answer questions with } \\
\text { answer option 1: never applied, up to 5: always applied } \\
\text { 4. Questions relating to management accounting practices consist of: } \\
\text { a. Accounting records used, includes: accounts receivable records, note payable records, } \\
\text { cash inflow records, cash outflow records, records of incoming goods, record of the goods } \\
\text { that came out, and record of consignment goods. Respondents were asked to answer } \\
\text { questions with answer option } 1 \text {. Not important, up to 5: very important } \\
\text { b. Preparation of Financial Statements. Questions asked about whether the respondent has } \\
\text { compiled financial statements on a regular basis }\end{array}$ \\
\hline 4 & Analysis of the data & Quantitative descriptive. The statistical indicator used is the mean (average). \\
\hline
\end{tabular}


2. Identify costs structure of respondents, which include: research and design costs, production costs, and marketing/distribution costs, as well as after-sales service costs.

3. Separating respondents based on low cost or differentiation strategies using the following steps:

(a) To get a calculation that can be used to separate the group of respondents, at the time of tabulation the opposite scale was used, in details are:

(1) Differentiation strategy: never applied (1)—applied intensively (5);

(2) Low Cost strategy: never applied (5)—applied intensivelly (1);

(3) Strategic MAS: never practiced (1)—practiced intensivelly (5);

(4) Traditional MAS: never practiced (5)—practiced intensivelly (1).

(b) Identify business units that implement low cost and differentiation strategies using the following procedures (Jermias \& Gani, 2005): If the average score of the answer is higher than the mean, the business unit is considered to implement a strategy which is tend to differentiation. Conversely, if the average score of answer is lower than the mean, the business unit is considered to implement a strategy which tends to low cost.

4. Analysis of the practice of management accounting system based on respondents' answers.

5. Based on the data obtained at Stage 3, analyzed descriptively whether the existing system is adequate to support the implementation of strategy.

\section{Result of the Research}

\section{Descriptive Analysis}

A total of 78 questionnaires were filled and returned by respondents. From the analysis, approximately $60 \%$ of respondents have exported or planned to export their products to overseas market. SMEs that have been exporting products are generally around Asia and some respondents export products to Europe and America. The types of products include batik products, garments, embroidery, knitwear, shoes, bags, and accessories products, for example, veil for Muslim or jilbab (hijab). For jilbab products, they are generally exported to Brunei, Malaysia and some countries where some people are Muslim. Most respondents (approximately 80\%) know that their products have competitors, and the toughest is the product from China, followed by India.

\section{Cost Structure}

Costs incurred by fashion-based SMEs include research and design costs, production costs, marketing/distribution costs, and consumer service costs. A total of 25 respondents or $24 \%$ of the respondents spend cost for research (survey), or at least to obtain information about products that are in demand by consumers. Regarding the cost to create designs, models, or motives, 49 respondents or $67 \%$ of the respondents spend the cost to get designs or motives that suit the interests or taste of consumers. In addition, there are 33 answers or $45 \%$ of respondents pay employees who specifically create a design or model, or specific motives in accordance with the consumer's interest.

In relation to the answers about production costs, total of $100 \%$ of respondents are pay the cost of raw materials, other materials, and labor costs. A total of 57\% calculated depreciation expenses on fixed assets used, which include buildings, machinery, and other equipment that used to support the production process. In addition, respondents also provide answers about other costs incurred, including electricity, water, telephone, and packing/packaging. Meanwhile, for marketing and distribution costs, a total of 53\% of respondents pay some fee for promotion or promotional costs. As much as $48 \%$ do promotion through social media (Instagram, 
Web, and Facebook), 20\% through exhibition, and 7\% of respondents do promotion by distributing catalogs and discounts. While the rest do promotion through other media, such as newspapers, magazines, and radio. Approximately 59\% of respondents have made sales online, and also pay the cost of online sales. Furthermore, on responses relating to after-sales service costs, $52 \%$ of all respondents received a product return, and about $49 \%$ of respondents were willing to pay compensation or reimbursement fees to customers. This facility provides the best service for its customers.

\section{Separation of Respondents Based on the Implementation of Competitive Strategies}

Using the procedure as described above, a total of 36 SMEs implement differentiation strategy, and thus, the rest apply a low cost strategy. Of these, a total of 20 SMEs who have been exporting or planning to export their products overseas implement a differentiation strategy. Meanwhile, there are 19 SMEs who have or plann to export their products and apply low cost strategy.

\section{Management Accounting Practices and Preparation of Financial Statements}

From the answers to the preparation of the financial statements, a total of 39 SMEs or $52 \%$ have not prepared the financial statements on a regular basis. SMEs who have prepared the financial statements on a regular basis, almost entirely prepare by themselves. Answers pertaining to accounting records that are considered most important by most respondents are accounts receivable records, followed by debt notes, cash inflow, and cash outflow records. As for notes on incoming and outgoing goods, respondents' answers ranged from "quite important" to "important".

This result means that in running the business, the owner or manager of the SME is not supported by adequate accounting records as a source of information. The data about cost are only recorded in the cash outflow records, as well as data on sales only recorded in the cash outflow records. Even, they take into account the depreciation cost but are also not recorded.

\section{Discussion of Research Results}

This section will analyze whether the existing system is adequate to support the implementation of strategy. Based on the data presented above, it appears that the fashion-based SMEs that have been sampled in this research, some of them have had overseas market (export), or at least, planned to export. Most of the SMEs that have not exported and exported already believe that Chinese products are the main competitors. This means, fashion-based SME products face competition, both at home and from abroad. To survive and develop, in fact, they have made product and marketing innovations. This can be seen from promotional models that have used social media, and even have made sales on line. But unfortunately, it was not properly administered, especially in relation to the record of expenses incurred.

An analysis that can be made on the results related to competitive strategy shows that almost $40 \%$ of respondents of this research implement a differentiation strategy. In accordance with contingency theory, SMEs implementing this strategy should be supported by adequate accounting management systems as the producer of useful information for decisions-making. Because the characteristics of the companies implementing this strategy are unique products, the necessary information is not only financial, but also non-financial, especially related to various aspects of the customer.

Marketing products that rely on uniqueness are very sensitive to changes in consumer tastes and competitor's products. Although these SMEs have done various innovations for the product and marketing, if 
not supported by adequate information systems, the owner is still not supported by adequate information for decision-making to respond to these two things. In the long run, this condition will certainly cause the performance achieved being not maximal or even threatened getting worse.

A deeper analysis that can be done is the fact that the data also indicate that most SMEs that were sampled in this study did not or have not yet prepared the financial statements. This result is in line with Mardiana's (2016) findings, that the information considered most important by SMEs is the supporting records, not the financial statement. This study found empirical evidence that accounting records that are considered important, are record for account receivables, account payable, cash inflow, and cash outflow. As a result, SMEs do not have access to the banking system or formal financial institutions (Chandrarin, 2017). This is understandable because financial institutions are not well informed about the performance and prospects of SMEs.

Some of the results of this study support previous studies that SMEs in Indonesia generally still managed simply. Facing increasingly tight competition, this condition must be changed immediately. Coaching conducted by the government, academia, NGOs, or other parties should consider aspects of improving the administration and information system. It is very necessary to complete the coaching that has been done, generally in the field of marketing, quality, and design. In connection with strategy implementation, good administration will also help SMEs to be able to perform various analyses in accordance with the strategy being implemented. If this can work well, then the competitive advantage of SMEs will also be improved.

\section{Conclusion}

This study has obtained empirical evidence regarding the implementation of strategy and practice of management accounting system in SMEs engaged in fashion-based creative sector. Based on data analysis, most of SMEs engaged in this field have not yet prepared financial statements. The most important accounting records are records of receivables and cash inflows-cash outflows. This condition should be improved immediately based on the analysis of the implementation of competitive strategy; some of SMEs engaged in the fashion sector implement differentiation strategy. Implementation of this strategy requires the support of adequate management accounting information for decision-making. Therefore, the direction of coaching and mentoring in this sector should not only focus on products and marketing but should begin guidance in the field of accounting, especially management accounting system as a provider of information that can be used as a basis for decision-making in accordance with the strategy implemented.

\section{Limitations of the Research}

1. This study uses questionnaires as data collection techniques. Because the respondents of this study are the owners and managers of SMEs fashion sector with a very diverse educational background; this allows a variety of perceptions also in understanding the question. As a result, the answers given by the respondents are largely determined by their perception and understanding of the question.

2. Data on the number of SMEs in the fashion sector in East Java are still not available, so it is difficult to determine how many samples are feasible for this study.

\section{Suggestion}

Further research should consider the number of samples to obtain accurate data. In addition, it highly recommended that data collection techniques not only use the questionnaire, but also need to be added with other techniques, such as interviews and observations. 


\section{References}

Anderson, S. W., \& Lanen, W. N. (1999). Economic transition, strategy and the evolution of management accounting practices: The case of India, Accounting, Organizations and Society, 24, 379-412.

Baines, A., \& Langfield-Smith, K. (2003). Antecedents to management accounting change: A structural equation approach. Accounting Organizations and Society, 28, 675-698.

Blocher, E. J., Stout, D. E., \& Cokins, G. (2010). Cost management a strategic emphasis (5th ed.). New York, NY: Mc. Graw Hill Companies.

Chandrarin, G. (2017). Financial and income equality. Proceeding of International Conference Sustainable Development Goals 2030: Challenges and Solutions. August 11-12, University of Merdeka Malang.

Chenhall, R. H. (2007). Theorising contingencies in management control systems research. In C. S. Chapman, A. G Hopwood, and M. D. Shields (Eds.), Handbook of management accounting research (Volume 1). Oxford, UK: Elsevier.

Gunadi, A. (2017). Potensi bangkitnya UMKM danIndustri kreatifmelalui "Peer-to-Peer Lending" (The potential for the rise of SMEs and the creative industry through "Peer-to-Peer Lending". Retrieved from https://ekonomi.kompas.com/read/2017/04/04/123000526/potensi-bangkitnya-umkm-dan-industri-kreatif-melalui-peer-to-pe er-lending-

Hansen, D. R., \& Maryanne M. M. (2007). Managerial accounting. 8th Edition, South-Western: Thomson.

Indonesian Central Bank. (2013). Laporan Bulanan Konsultan Pengembangan Usaha Mikro dan Menengah (Monthly report of micro and medium enterprise development consultant) (Unpublished research).

Indonesian Central Bank. (2015). Penelitian Pengembangan komoditas, Produk, dan Jenis Usaha Unggulan UMKM di Jawa Timur (Research on the development of commodities, products, and types of business priorities for SMEs in East Java) (Unpublished research).

Indonesian Ministry of Industry. (2009). Pengembangan Klaster Industri Prioritas, Industri Penunjang Industri Kreatif DanIndustri Kreatif TertentuTahun 2010-2014 (The development of priority industrial cluster, creative industry supporting industries, and certain creative industries, 2010-2014). Retrieved from http://digilib.usu.ac.id/buku/

Jermias, J., \& Gani, L. (2004). Integrating business strategy, organizational configurations and management accounting systems with business unit effectiveness: A fitness landscape approach. Management Accounting Research, 15, 179-200.

Jermias, J., \& Gani, L. (2005). Ownership structure, contingent-fit, and business-unit performance: A research model and empirical evidence. The International Journal of Accounting, 40, 65-85.

Kontan, 19 July, 2017. Memacu kontribusi ekonomi kreatif (Encouraging the contribution of the creative economy). Retrieved from https://m.kontan.co.id/news_analisis/memacu-kontribusi-ekonomi-kreatif

Langfield-Smith, K. (2006). Understanding management control systems and strategy. In A. Bhimani (Ed.), Contemporary issues in management accounting (pp. 243-265). New York, USA: Oxford University Press.

Langfield-Smith, K. (2007). A review of quantitative research in management control system and strategy. In C. S. Chapman, A. G Hopwood, and M. D. Shields (Eds.), Handbook of management accounting research (Volume 1). Oxford, UK: Elsevier.

Mardiana, A. (2016). Effect of system quality, quality of information and top management support on perceifed usefulness and its impact on SME managers as end user of accounting information (Dissertation, University of Merdeka Malang).

Ministry of Tourism and Creative Economy of the Republic of Indonesia. (2014). EkonomiKreatif: KekuatanBaru Indonesia Menuju 2025 (Creative economy: Indonesia's new strength towards 2025). Retrieved from http://www.researchgate.net/publication/321753429_Ekonomi_kreatif_Kekuatan_baru_Indonesia_menuju_2025

Ministry of Trade of the Republic of Indonesia. (2015). IFW 2015 DorongProdukFesyen Indonesia MenujuPasar Global (IFW 2015 encourages Indonesia's products into global markets). Retrieved from http://ifw-2015-dorong-produk-fesyen-indonesia-menuju-pasar-global-id0-1424170138

Muslikhah, R. I. (2014). Development of the fashion industry as a leading creative industry to encourage Indonesian economic development (Thesis, Magister in Economic Education, University of Sebelas Maret, Surakarta).

Mutmainah, D. A. (2016). Kontribusi UMKM Terhadap PDB Tembus Lebih Dari 60 Persen (SME contribution to GDP reaches more than 60 percent). CNN Indonesia. Retrieved from https://www.cnnindonesia.com

Nishimura, A. (2005). Fundamental features and perspectives of management accounting in Asia. In A. Nishimura and R. Willet (Eds.), Management accounting in Asia. Singapore: Thomson Learning.

Organisation for Economic Co-operation and Development (OECD). (2015). Survei Ekonomi OECD Indonesia. Retrieved from http://www.oecd.org/eco/surveys/economic-survey-indonesia-2015.htm 
Phadoongsitthi, M. (2003). The role of managerial accounting in emerging economies: An empirical study of Thailand (Dissertation, University of Maryland).

Porter, M. (1980). Competitive Strategy: Techniques for Analyzing Industries and Competitors. New York: Free Press.

Subagja, I. K. (2017). Creative industry competitiveness in Indonesia: Study on creative industry map. Proceeding of International Conference on Sustainable Development Goals 2030: Challenges and Its Solutions. August 11-12, University of Merdeka Malang.

Subagya, I. K. (2017). Creative industry competitiveness in Indonesia: Study on creative industry map. Proceeding of International Conference Sustainable Development Goals 2030: Challenges and Solutions. August 11-12, University of Merdeka Malang. 